\title{
Forest ecosystem responses to environmental changes: the key regulatory role of biogeochemical cycling
}

\author{
Chengrong Chen $\cdot$ Zhihong Xu
}

Received: 25 November 2009 / Accepted: 25 November 2009/Published online: 18 December 2009

(C) Springer-Verlag 2009

\section{Introduction}

Forests cover ca. 42 million square kilometer in tropical, temperate, and boreal lands (ca. $30 \%$ of the land surface), store ca. $45 \%$ of terrestrial C, contribute ca. $50 \%$ of terrestrial net primary production, and harbor two thirds of terrestrial biodiversity (Bonan 2008; Purves and Pacala 2008; Xu et al. 2009). These forests not only provide timber and nontimber forest products, but more importantly, ecological services such as biodiversity and protection of watershed and soil resources and sequestration of C (Dixon et al. 1994; Chen et al. 2004a; Lamb et al. 2005; Purves and Pacala 2008). The N, P, and C interact in their biogeochemical cycles in ecosystems, and the stoichiometric balance is essential for maintaining forest ecosystem diversity, functioning, and stability (Wardle et al. 2004; Chen et al. 2005; Davidson et al. 2007). Environmental changes such as elevated atmospheric $\mathrm{CO}_{2}$ and temperature, atmospheric $\mathrm{N}$ deposition, land-use change, and forest fires, have transformed much of the land surface on the earth in the past century (e.g., Wardle et al. 2004; Pan et al. 2008, 2009). It is essential to understand the ecosystem responses to these changes and the underlying processes regulating the responses (Dahlgren 2006). These environmental changes resulting mainly from anthropogenic activities have altered the biogeochemical cycles of $\mathrm{C}$ and N (Gruber and Galloway 2008). However, little is known about how the increased $\mathrm{C}$ and $\mathrm{N}$ by elevated $\mathrm{CO}_{2}$ and $\mathrm{N}$ deposition and the loss of $\mathrm{C}$ and $\mathrm{N}$ by fires affect biogeochemical cycling of other elements (e.g., P; Gruber

\section{Chen $(\bowtie) \cdot Z$. Xu}

Environmental Futures Centre and Griffith

School of Environment, Griffith University,

Nathan, QLD 4111, Australia

e-mail: c.chen@griffith.edu.au and Galloway 2008), how the interactions among C, N, and $\mathrm{P}$ cycles regulate forest ecosystem response to these changes, how the soil microbial community responds to these stoichiometry changes and mediate $\mathrm{C}, \mathrm{N}$, and $\mathrm{P}$ cycling processes under these changes, and how the aboveground and belowground processes are linked in response to these changes. In addition, impacts of interactions of these environmental changes on ecosystem processes are largely unknown (Knops et al. 2007; Gruber and Galloway 2008; He et al. 2009).

\section{Impacts of environmental changes on the belowground ecosystem processes}

\subsection{Elevated atmospheric $\mathrm{CO}_{2}$}

The global annual emissions of $\mathrm{CO}_{2}$ have grown between 1970 and 2004 by about $80 \%$ and are projected to increase by $40-110 \%$ between 2000 and 2030 (IPCC 2007). Elevated atmospheric $\mathrm{CO}_{2}$ leads to enhanced photosynthetic rate and growth and increased $\mathrm{C}$ inputs to the underground through root exudation and turnover and litterfall and affects ecosystem function and stability in the long term (Oren et al. 2001; Hyvönen et al. 2007; Lagomarsino et al. 2009). Elevated $\mathrm{CO}_{2}$ alters nutrient concentrations of plant tissues and produces energy-rich but nutrient-poor litter with higher $\mathrm{C}: \mathrm{N}$ ratios (Norby et al. 2001; Kurz-Besson et al. 2006). However, the effects of elevated $\mathrm{CO}_{2}$ on litter decomposition are uncertain (Knops et al. 2007; Hyvönen et al. 2007). The impact of elevated $\mathrm{CO}_{2}$ on the availability and turnover of soil $\mathrm{P}$ (particularly organic $\mathrm{P}$ ) and its interactions with $\mathrm{C}$ and $\mathrm{N}$ is largely unknown. The elevated $\mathrm{CO}_{2}$ may increase root exudation and then solubilization of soil $\mathrm{P}$ and tree $\mathrm{P}$ uptake (Delucia et al. 1997). Increased C:P ratios in organic substrates (leaf, 
root litters, etc.) induced by elevated $\mathrm{CO}_{2}$ lead to the $\mathrm{P}$ limitation, which can in turn affect ecosystem responses to global climate changes (Hungate et al. 2003). Effects of elevated $\mathrm{CO}_{2}$ on microbial biomass, activity, and composition are variable and far from predictable (e.g., KaoKniffin and Balser 2007). Recently, Austin et al. (2009) found that elevated $\mathrm{CO}_{2}$ had no detectable effects on microbial community structure.

\subsection{Atmospheric $\mathrm{N}$ deposition}

Total $\mathrm{N}$ deposition is estimated to be nearly twofold greater by 2050 compared with deposition in the early 1990s due to continuous emissions of increased anthropogenic $\mathrm{N}$ on a global scale (Galloway et al. 2004). Atmospheric N deposition is known to be responsible for reduced plant diversity in natural and seminatural ecosystems (Phoenix et al. 2006). Atmospheric $\mathrm{N}$ deposition may initially increase $\mathrm{N}$ availability, $\mathrm{N}$ mineralization, and nitrification and thus, forest growth in the N-limiting areas (Aber et al. 1998; Horswill et al. 2008). Chronic N deposition can cause nutrient imbalances, acidification, base cation depletion, nitrate leaching, and water pollution (Aber et al. 1998; Horswill et al. 2008). At the later stage of $\mathrm{N}$ deposition, mineralization rate may decrease (Aber et al. 1998) and nutrient (e.g., P) limitation becomes a constraint to additional increases in productivity. Atmospheric $\mathrm{N}$ deposition modifies elemental composition of plant tissues, litters, and soil by decreasing C:N ratios and increasing $\mathrm{N}: \mathrm{P}$ ratios (Månsson and Falkengren-Grerup 2003; Horswill et al. 2008) and lignin content (Knops et al. 2007), but impacts of $\mathrm{N}$ deposition on decomposition of litter is uncertain (e.g., Manning et al. 2008). The enhanced N availability induced by continued $\mathrm{N}$ deposition will increase $\mathrm{P}$ demand, which favors depletion of inorganic $\mathrm{P}$. The availability and turnover of organic $\mathrm{P}$ will become important and may regulate the effects of atmospheric $\mathrm{N}$ deposition. Some temperate forests have moved from $\mathrm{N}$ limitation to $\mathrm{P}$ limitation due to $\mathrm{N}$ deposition (e.g., Akselsson et al. 2008). Atmospheric $\mathrm{N}$ deposition modifies soil microbial communities by direct effects on substrate quality and soil chemistry (e.g., acidification) and indirect effects by changing plant species composition and then affecting soil microbial community. Frey et al. (2004) found that $\mathrm{N}$ deposition decreased active fungal biomass and altered the pattern of microbial substrate use. But Waldrop et al. (2004) showed that response of microbial community to $\mathrm{N}$ deposition is ecosystem specific.

\subsection{Forest fire}

Fire profoundly modifies the terrestrial cycle of ca. $40 \%$ of land surface on the earth (Alexis et al. 2007) and plays an important ecological role in shaping natural rainforest ecosystems. Impacts of fire on soil depend upon its intensity, frequency, forest type, the slope, and fuel load (Knicker 2007). In general, immediate impacts of fire are the loss of $\mathrm{C}$ and $\mathrm{N}$ as gases and particulates into atmosphere from the ecosystem, while $\mathrm{P}$ remains in soil (Hungate et al. 2003; Carter and Foster 2004: Alexis et al. 2007). Some work has also shown that low intensity fire may have minor effects (e.g., Knicker 2007). Fire can increase immediate $\mathrm{N}$ availability (increases in $\mathrm{NO}_{3}{ }^{-}-\mathrm{N}$ and/or $\mathrm{NH}_{4}{ }^{+}-\mathrm{N}$; Carter and Foster 2004). However, little is known about the impacts of fires on the amount and nature of soil P. Fires may increase P availability (Carter and Foster 2004). Changes in stoichiometry (i.e., decreased C: $\mathrm{P}$ and N:P ratios) induced by fires can have significant impacts on the soil $\mathrm{P}$ cycling and the interactions of biogeochemical cycles of $\mathrm{C}$ and $\mathrm{N}$, which is still largely unknown. Further, the long-term impacts of these stoichiometric changes on the aboveground forest growth and productivity, species composition, and the belowground microbial community composition and activity have not been studied. In particular, in P-limiting forests, the increased $\mathrm{P}$ availability and the decreased $\mathrm{N}: \mathrm{P}$ ratio resulting from the forest fire may encourage the growth of P-demanding species, which could not grow well previously and further change soil microbial community composition. Fire alters the soil microbial community structure in the short-term primarily through heat-induced microbial mortality. Over the long-term, fire may modify soil community by altering plant community composition via plant-induced changes in the soil environment (Hart et

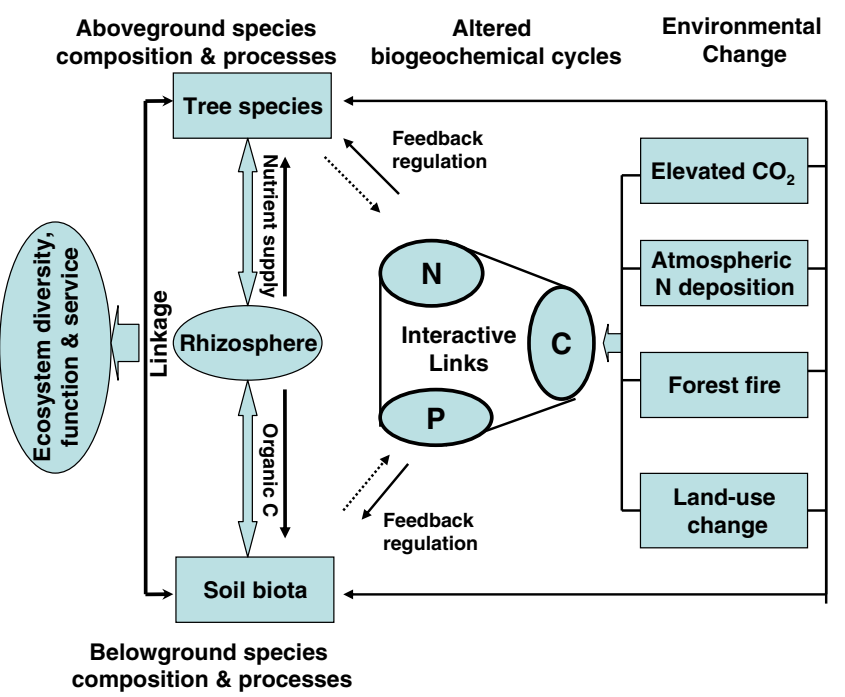

Fig. 1 Hypothetical framework on the impacts of environmental changes (elevated atmospheric $\mathrm{CO}_{2}$ and $\mathrm{N}$ deposition, fires, and landuse change) on forest ecosystem processes and regulation of the ecosystem responses to the environmental changes 
al. 2005). Bacteria are more resistant to fire than fungi (González-Pérez et al. 2004). Repeated burning significantly reduced fungal biomass and mycorrhizal abundance and modified the fungal community structure (Hart et al. 2005).

\subsection{Land-use change}

Land-use change is a global phenomenon in response to changes in political, social, economic, or environmental conditions (Rudel et al. 2005) and the consequences of land-use change have been widely recognized (e.g., Rudel et al. 2005; Chen et al. 2008; de Chazal and Rounsevell 2009; Lu et al. 2009; Pan et al. 2009). These include its potential effects on carbon sequestration, soil quality, longterm sustainability, and the water and environmental quality (e.g., Fahey and Jackson 1997; Rudel et al. 2005; Richards et al. 2007; Macdonald et al. 2009). The impact of land-use changes on the ecosystem processes depends mainly on plant species and associated management practices (e.g., Chen et al. 2008; Chen and Xu 2008; Pan et al. 2008, 2009). It has been reported that land-use change from grassland to plantation forest enhanced the availability of soil P and other nutrients (e.g., Chen et al. 2000; Chen et al. 2003), while other studies suggested that land-use change from native forest to plantation forest decreased $\mathrm{C}$ and $\mathrm{N}$ availability (e.g., Chen et al. 2004b; Burton et al. 2007; Xu et al. 2008). Shifts in $C$ and nutrient availability and balance would affect soil microbial community composition and functioning (Chen et al. 2004a, b; He et al. 2005; Macdonald et al. 2009). Land-use change is also a key driver of biodiversity change (e.g., Fischlin et al. 2007; de Chazal and Rounsevell 2009). Complex interactions of land-use change and other environmental changes make it difficult to estimate its effects on ecosystem biodiversity and function when the land-use change effects are examined alone.

\section{Biogeochemical cycling regulates ecosystem responses to the environmental changes}

Biogeochemical cycling processes play a vital role in the establishment or degradation of forests by regulating the natural and human impacts on forest ecosystems across a wide range of spatial and temporal scales (Wardle et al. 2004; Dahlgren 2006). Impacts of environmental changes on the interactions of $\mathrm{C}, \mathrm{N}$, and P biogeochemical cycles, and the role of these biogeochemical processes in regulating ecosystem responses to environmental changes are largely unknown. Here, we put forward the hypothetical framework (Fig. 1) in an attempt to elucidate impacts of environmental changes and biogeochemical regulation of ecosystem responses to these changes. Elevated $\mathrm{CO}_{2}$ and atmospheric $\mathrm{N}$ deposition decrease relative $\mathrm{P}$ availability by increasing $\mathrm{C}$ and $\mathrm{N}$ inputs to the forest ecosystem, respectively. This results in increases in $\mathrm{C}: \mathrm{P}$ and N:P ratios in soil organic substrates and altered biogeochemical cycles of $\mathrm{C}, \mathrm{N}$, and $\mathrm{P}$, which may lead to the shift in the soil microbial community composition and function and thus, the aboveground species composition and growth and then regulate ecosystem responses to the elevated $\mathrm{CO}_{2}$ and the $\mathrm{N}$ deposition. Fire causes losses of soil $\mathrm{C}$ and $\mathrm{N}$ but $\mathrm{P}$ remains. This leads to an increase in relative $P$ availability by decreasing $C: P$ and $N: P$ ratios and changes in the chemical nature of soil organic P. This may cause changes in soil microbial community composition and activity and the aboveground forest growth and species composition. Land-use change, as previously discussed, also leads to the shifts in soil $\mathrm{C}$ and nutrient availability and stoichiometric balance, which in turn will affect soil microbial community composition and function and then the aboveground ecosystem processes.

In conclusion, ongoing natural and anthropogenic environmental changes such as increased atmospheric $\mathrm{CO}_{2}$ and $\mathrm{N}$ deposition, fires, and land-use change have significantly impacts on the belowground ecosystem processes, and the forest ecosystem responses to the environmental change are likely to be regulated by interactive biogeochemical cycling processes. The environmental changes frequently occur at the same time and the interactions among these changes are very complicated. The mechanisms involved in the biogeochemical regulation of ecosystem responses to the environmental changes are largely unknown and warrant a detailed study using multiple disciplinary approaches, including soil chemistry, microbial ecology, plant physiology, and molecular biology.

\section{References}

Aber J, MaDowell W, MNadelhoffer K, Magill A, Bernston G, Kamakea M, McNulty S, Currie W, Rustad L, Fernandez I (1998) Nitrogen saturation in temperate forest ecosystems. Bioscience 48:921-934

Akselsson C, Westling O, Alveteg M, Thelin G, Fransson A-M, Hellsten S (2008) The influence of N load and harvest intensity on the risk of P limitation in Swedish forest soils. Sci Total Environ 404: 284-289

Alexis MA, Rasse DP, Rumpel C, Bardoux G, Péchot N, Schmalzer P, Drake B, Mariotti A (2007) Fire impact on C and N losses and charcoal production in a scrub oak ecosystem. Biogeochem 82:201-216

Austin EE, Castro HF, Sides KE, Schadt CW, Classen AT (2009) Assessment of 10 years of $\mathrm{CO}_{2}$ fumigation on soil microbial communities and function in a sweetgum plantation. Soil Biol Biochem 41:514-540

Bonan GB (2008) Forests and climate change: forcings, feedbacks, and the climate benefits of forests. Science 320:1444-1449 
Burton J, Chen CR, Xu ZH, Ghadiri H (2007) Gross nitrogen transformations in adjacent native and plantation forests of subtropical Australia. Soil Biol Biochem 39:426-433

Carter MC, Foster CD (2004) Prescribed burning and productivity in southern pine forests: a review. For Ecol Manage 191:93-109

Chen CR, Xu ZH (2008) Analysis and behaviour of soluble organic nitrogen in forest soils. J Soils Sediments 8:363-378

Chen CR, Condron LM, Davis MR, Sherlock RR (2000) Effects of afforestation on phosphorus dynamics and biological properties in a New Zealand grassland soil. Plant Soil 200:151-163

Chen CR, Condron LM, Davis MR, Sherlock RR (2003) Seasonal dynamics of soil phosphorus and associated microbial properties under adjacent grassland and forest in New Zealand. For Ecol Manage 177:539-557

Chen CR, Xu ZH, Mathers NJ (2004a) Soil carbon pools in adjacent natural and plantation forests of subtropical Australia. Soil Sci Soc Am J 68:282-291

Chen CR, Condron LM, Davis MR, Sherlock RR (2004b) Effects of plant species on soil microbial biomass and phosphatase enzyme activity. Biol Fertil Soils 40:313-322

Chen CR, Xu ZH, Zhang SL, Keay P (2005) Soluble organic nitrogen pools in forest soils of subtropical Australia. Plant Soil 277:285-297

Chen CR, Condron LM, Xu ZH (2008) Impacts of grassland afforestation on soil phosphorus dynamics and associated microbial processes: a review. For Ecol Manage 255:396-409

Dahlgren RA (2006) Biogeochemical processes in soils and ecosystems: from landscape to molecular scale. J Geochem Explor 88:186-189

Davidson EA, de Carvalho CJR, Figueira AM, Ishida FY, Ometto JPHB, Nardoto GB, Saba RT, Hayashi SN, Leal EC, Vieira ICG, Martinelli LA (2007) Recuperation of nitrogen cycling in Amazonian forests following agricultural abandonment. Nature 447:995-998

De Chazal J, Rounsevell MDA (2009) Land-use and climate change within assessments of biodiversity change: a review. Glob Environ Change 19:306-315

Delucia EH, Callaway RM, Thomas EM, Schlesinger WH (1997) Mechanisms of phosphorus acquisition for ponderosa pine seedlings under high $\mathrm{CO}_{2}$ and temperature. Ann Bot 79:111-120

Dixon RK, Brown S, Houghton RA, Solomon AM, Trexler MC, Wisniewski J (1994) Carbon pools and flux of global forest ecosystems. Science 263:185-190

Fahey B, Jackson R (1997) Hydrological impacts of converting native forests and grasslands to pine plantations, South Island, New Zealand. Agri For Meteorol 84:69-82

Fischlin A, Midgley GF, Price JT, Leemans R, Copal B, Turley C, Rounsevell MDA, Duke OP, Tarazona J, Velichko AA (2007) Ecosystems, their properties, goods and services. In: Parry ML, Canziani OF, Palutikof IP, van der Linden PJ, Hanson CE (eds) Climate change 2007: impacts, adaptation and vulnerability. Contribution of working group II to the 4th assessment report of the Intergovernmental Panel of Climate Change (IPCC). Cambridge University Press, Cambridge, UK, pp 211-272

Frey SD, Knorr M, Parrent JL, Simpson RT (2004) Chronic nitrogen enrichment affects the structure and function of the soil microbial community in temperate hardwood and pine forests. For Ecol Manage 196:159-171

Galloway JN, Dentener FJ, Capone DG, Boyer EW, Howarth RW, Seitzinger SP, Asner GP, Cleveland CC, Green PA, Holland EA, Karl DM, Michaels AF, Porter JH, Townsend AR, Voumlosmarty CJ (2004) Nitrogen cycles: past, present, and future. Biogeochem 70:153-226

Gonzalez-Perez JA, Gonzalez-Vila FJ, Almendros G, Knicker H (2004) The effect of fire on soil organic matter-a review. Environ Int 30:855-870

Gruber N, Galloway JN (2008) An earth-system perspective of the global nitrogen cycle. Nature 451:293-296
Hart SC, DeLuca TH, Newman GS, MacKenzie MD, Boyle SI (2005) Post-fire vegetative dynamics as drivers of microbial community structure and function in forest soils. For Ecol Manage 220:166-184

He JZ, Xu ZH, Hughes J (2005) Soil fungal communities in adjacent natural forest and hoop pine plantation ecosystems as revealed by molecular approaches based on $18 \mathrm{~S}$ rRNA genes. FEMS Microbiol Lett 247:91-100

He JZ, Ge Y, Xu ZH, Chen CR (2009) Linking soil bacterial diversity to ecosystem multifunctionality using backward-elimination boosted trees analysis. J Soils Sediments 9:547-554

Horswill P, O'Sullivan O, Phoenix GK, Lee JA, Leake JR (2008) Base cation depletion, eutrophication and acidification of species-rich grasslands in response to long-term simulated nitrogen deposition. Environ Pollut 155:336-349

Hungate BA, Dukes JS, Shaw MR, Luo YQ, Field CB (2003) Nitrogen and climate change. Science 302:1512-1513

Hyvönen R, Agren GI, Linder S, Persson T, Cotrufo MF, Ekblad A, Freeman M, Grelle A, Janssens IA, Jarvis PG, Kellomaki S, Lindroth A, Loustau D, Lundmark T, Norby RJ, Oren R, Pilegaard K, Ryan MG, Sigurdsson BD, Stromgren M, van Oijen $\mathrm{M}$, Wallin $\mathrm{G}$ (2007) The likely impact of elevated $\left[\mathrm{CO}_{2}\right]$, nitrogen deposition, increased temperature and management on carbon sequestration in temperate and boreal forest ecosystems: a literature review. New Phytol 173:463-480

IPCC (2007) Fourth assessment report. Cambridge University Press, Cambridge

Kao-Kniffin J, Balser TC (2007) Elevated $\mathrm{CO}_{2}$ differentially alters belowground plant and soil microbial community structure in reed canary grass-invaded experimental wetlands. Soil Biol Biochem 39:517-525

Knicker H (2007) How does fire affect the nature and stability of soil organic nitrogen and carbon? A review. Biogeochem 85:91-118

Knops JMH, Naeem S, Reich PB (2007) The impact of elevated $\mathrm{CO}_{2}$, increased nitrogen availability and biodiversity on plant tissue quality and decomposition. Glob Change Biol 13:1960-1971

Kurz-Besson C, Coûteaux MM, Berg B, Remacle J, Ribeiro C, Romanyà $\mathrm{J}$, Thiéry JM (2006) A climate response function explaining most of the variation of the forest floor needle mass and the needle decomposition in pine forests across Europe. Plant Soil 285:97-114

Lagomarsino A, De Angelis P, Moscatelli MC, Grego S (2009) The influence of temperature and labile $\mathrm{C}$ substrates on heterotrophic respiration in response to elevated $\mathrm{CO}_{2}$ and nitrogen fertilization. Plant Soil 317:223-234

Lamb D, Erskine PD, Parrotta JA (2005) Restoration of degraded tropical forest landscapes. Science 310:1628-1632

Lu J, Hu ZY, Xu ZH, Cao ZH, Zhuang SY, Yang LZ, Lin XG, Dong YH, Yin R, Ding JL, Zheng YF (2009) Effects of rice cropping intensity on soil nitrogen mineralization rate and potential in buried ancient paddy soils from the neolithic age in China's Yangtze River Delta. J Soils Sediments 9:526-536

Macdonald CA, Thomas N, Robinson L, Tate KR, Ross DJ, Dando J, Singh BK (2009) Physiological. Biochemical and molecular response of the soil microbial community after afforestation of pastures with Pinus radiata. Soil Biol Biochem 41:1642-1651

Manning P, Saunders M, Bardgett RD, Bonkowski M, Bradford MA, Ellis RJ, Kandeler E, Marhan S, Tscherko D (2008) Direct and indirect effects of nitrogen deposition on litter decomposition. Soil Biol Biochem 40:688-698

Månsson KF, Falkengren-Grerup U (2003) The effect of nitrogen deposition on nitrification, carbon and nitrogen mineralisation and litter C:N ratios in oak (Quercus robur L.) forests. For Ecol Manage 179:455-467

Norby RJ, Cotrufo MF, Ineson P, O’Neill EG, Canadell J (2001) Elevated $\mathrm{CO}_{2}$, litter chemistry, and decomposition: a synthesis. Oecologia 127:153-165 
Oren R, Ellsworth D, Johnsen K, Phillips N, Ewers B, Maier C, Schäfer K, McCarthy H, Hendrey G, McNulty S, Katul G (2001) Soil fertility limits carbon sequestration by forest ecosystems in a $\mathrm{CO}_{2}$-enriched atmosphere. Nature 411:469-472

Pan KW, Xu ZH, Blumfield TM, Totua S, Lu MX (2008) In situ mineral ${ }^{15} \mathrm{~N}$ dynamics and fate of added ${ }^{15} \mathrm{NH}_{4}{ }^{+}$in hoop pine plantation and adjacent native forest in subtropical Australia. J Soils Sediments 6:398-405

Pan KW, Xu ZH, Blumfield TM, Tutua S, Lu MX (2009) Application of $\left({ }^{15} \mathrm{NH}_{4}\right)_{2} \mathrm{SO}_{4}$ to study $\mathrm{N}$ dynamics in hoop pine plantation and adjacent native forest of subtropical Australia: the effects of injection depth and litter addition. J Soils Sediments 9:515-525

Phoenix GK, Hicks WK, Cinderby S, Kuylenstierna JCI, Stock WD, Dentener FJ, Giller KE, Austin AT, Lefroy RDB, Gimeno BS, Ashmore MR, Ineson P (2006) Atmospheric nitrogen deposition in world biodiversity hotspots: the need for a greater global perspective in assessing $\mathrm{N}$ deposition impacts. Glob Change Biol 12:470-476

Purves D, Pacala S (2008) Predictive models of forest dynamics. Science 320:1452-1453
Richards AE, Dalal RC, Schmidt S (2007) Soil carbon turnover and sequestration in native subtropical tree plantations. Soil Biol Biochem 39:2078-2090

Rudel TK, Coomes OT, Moran E, Achard F, Angelsen A, Xu J, Lambin E (2005) Forest transitions: towards a global understanding of land use change. Glob Environ Change, Part A 15:23-31

Waldrop MP, Zak DR, Sinsabaugh RL (2004) Microbial community response to nitrogen deposition in northern forest ecosystems. Soil Biol Biochem 36:1443-1451

Wardle DA, Walker LR, Bardgett RD (2004) Ecosystem properties and forest decline in contrasting long-term chronosequences. Science 305:509-513

Xu ZH, Ward S, Chen CR, Blumfield T, Prasolova NV, Liu JX (2008) Soil carbon and nutrient pools, microbial properties and gross nitrogen transformations in adjacent natural forest and hoop pine plantations of subtropical Australia. J Soils Sediments 8:99-105

$\mathrm{Xu}$ ZH, Chen CR, He JZ, Liu JX (2009) Trends and challenges in soil research 2009: linking global climate change to local long-term forest productivity. J Soils Sediments 9:83-88 